\title{
Integration of supply chain management and tourism: An empirical study from the hotel indus- try of Indonesia
}

\author{
Muhammad Arifin ${ }^{a^{*}}$, Andi Ibrahim ${ }^{\mathrm{b}}$ and Muhammad Nur
}

${ }^{a}$ Politeknik Pariwisata Makassar, Indonesia

${ }^{b}$ Universitas Islam Negeri Alauddin Makassar, Indonesia

${ }^{c}$ Sekolah Tinggi Ilmu Ekonomi Enam Enam, Kendari, Indonesia

CHRON I CLE ABSTRACT

Article history:

Received: October 4, 2018

Received in revised format: No-

vember 19, 2018

Accepted: November 25, 2018

Available online:

November 25, 2018

\section{Keywords:}

Supply chain management

Tourism industry

Regression analysis

Indonesia

\begin{abstract}
The idea of supply chain management (SCM) is covering its perspective in the form of flow of material and information from the business to customers. Its application in the field of tourism is also very much significant. The objective of present study is to analyze the empirical association between the supply chain management and tourism industry from the context of hotel industry in Indonesia. For this purpose, a questionnaire-based approach is followed while taking the demographic factors regarding age, gender and qualification. A sample of 272 respondents is finally accepted for the empirical examination between supply chain and its implication in tourism industry. Both descriptive and regression analysis are conducted. To analyze the factor of supply chain, sixteen items are considered from the existing literature while considering the strategic supplier partnership, information sharing, and information quality as the key indicators. The factor of tourism is measured through four different proxies. The practical implications of the study are taken both the tourists and key policymakers while dealing with the SCM and its integration with those hotels dealing with the tourism and related services. This study contributes towards the future trends in the form of integration for SCM and tourism industry.
\end{abstract}

\section{Introduction}

Among the other economic indicators, the tourism industry of any country in the global context is considered as the growing sector. As per the findings of United National World Tourism Organization (UNWTO), it is found that after the world war II, the idea of tourism has been significantly increasing in the world economy (Szpilko, 2017). This increase is recorded both in terms of a number of tourists $\&$ trip along with the revenue form the tourism industry. During the time span of the 1950s to onward, the number of international tourist revenue has been increased from 25 million US dollars to 1186 billion US dollars in 2015. This significant increase in the revenue graph has provided enough evidence to state that the growth of the tourism industry is with the rapid speed. As per the contribution in the world economy regarding growth domestic product (GDP), the portion of tourist earning has covered almost 9.8 percent in the year 2015 (Szpilko, 2017). To provide the customer with the significant service specifically in the field of tourism, the need of dynamic development and working to compete in the market can handle customer's expectations (Buhalis \& Law, 2008; Eraqi, 2006). To work for the

* Corresponding author.

E-mail address: marifin@poltekpar-makassar.ac.id (M. Arifin) 
best of the customers even in the tourism industry, business firms specifically the hotels must deal with the innovative servicing ideas. However, the idea of supply chain management is among the main contributor as various firms are interlinked to cooperate for the tourism supply chain (Alford, 2005; Sigala, 2008). In the overall tourist market, the association and cooperation between the business firms can provide and develop a success factor by focusing on supply chain management. However, in the overall process of the integration between supply chain and tourism industry, tourism supply chain is explained by many researchers (e.g. Zhang et al., 1999; Zhang et al., 2006). They stated the fact that tourism supply chain (TSC) is truly a network/system of various organizations dealing in such activity, ranging from the provision of various products/services (Alford, 2005; Sigala, 2008; Briandana et al., 2018). TSC covers both the public and private sector, products and services, accommodations, and finally the sales and marketing activities. Meanwhile, the shape of tourism supply chain is based on the tourist product which considers the regions and cities as well (Ashworth \& Voogd, 1994; García-Rosell et al., 2007). With the passage of time, the idea of the evolution of tourism has covered several dimensions and key participants like the suppliers, travel agents, clients and customers. In the field of marketing channels, the significant obligation belongs to the tour-operator is to take over the serviced being offered by the various categories of the supplier and finally "packing" them in a proper way. In this regard, tourist operators have their meaningful contribution while integrating the supplier's activities and those are dealing with the retailing (Muhcină \& Popovici, 2008; Okon, 2014; Khan \& Rasheed, 2016; Hussien \& Jones, 2016; Taqi et al., 2018; Yu-Chi, 2018).

From the context of Indonesia, the tourism industry has increased its contribution towards the GDP for the past several years. The reason is that it has triggered more foreign exchange income on average and generates from USD1100\$ to $1200 \$$ per visitor. Meanwhile, this increasing earning also provides the employment opportunities to the local people as per the latest findings of Statistics Indonesia. This employment opportunity has stopped the unemployment rate at 5.81 percent and it is also observed that overall 9 percent of the workforce in the country is related to the tourism, industry either directly or indirectly. In the recent year, the overall contribution of the tourism industry is about 8 percent on the overall economy. The target of the local government is to increase this contribution by the end of 2018 to almost 16 percent, which requires almost 20 million visitors in one year. To achieve this objective government has improved various components of infrastructure, health and hygiene along with the online promotion of tourism in the country. In addition, the Indonesian Government has also focused on the Visa-free access policy from 2015 to attract the tourists in the country. Fig. 1 shows the arrival of various tourists in Indonesia.

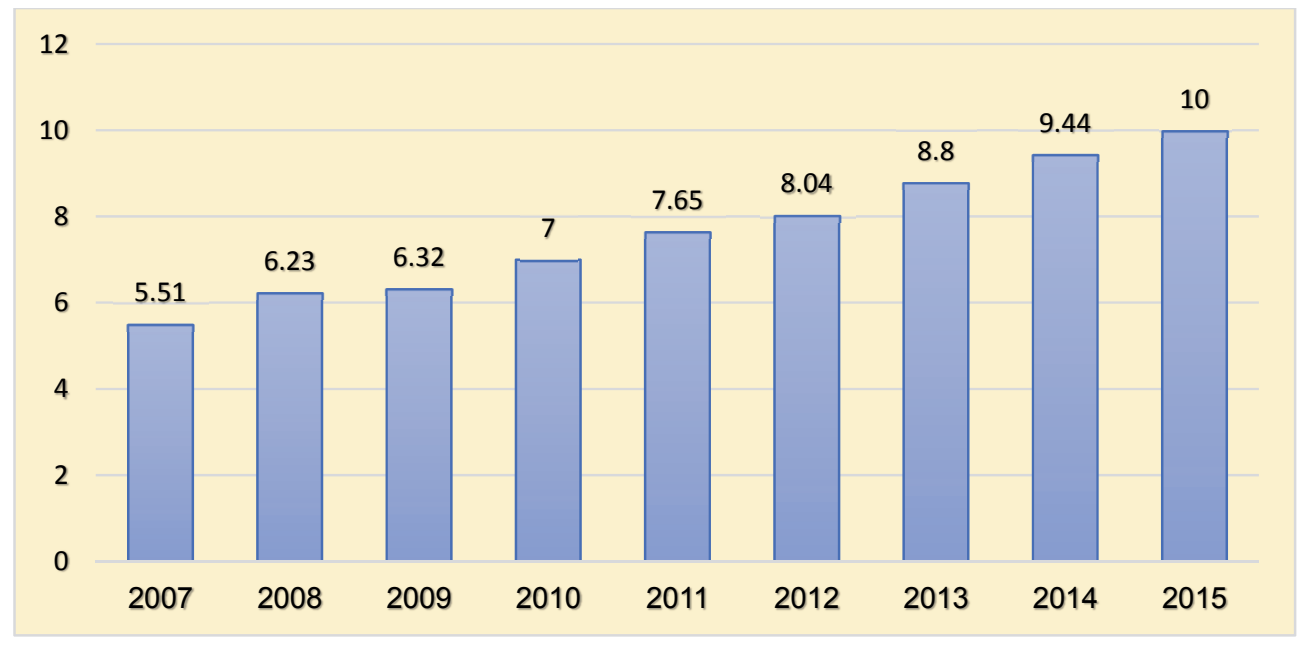

Fig. 1. Foreign Tourist Arrivals in Indonesia, 2007-2015

The next part of the paper is as follows. Section 2 covers the literature context in the field of supply chain and tourism. Section 3 deals with the description of the variables and methods being adopted for 
the study. Sector 4 provides the details of the results and analysis. The final section describes the conclusions, and limitations along with future recommendations.

\section{Literature Review}

The idea of supply chain management in the field of tourism is addressed in some studies, still, there is a significant gap to cover. However, the evaluation of tourism-related activities covers many participants, suppliers who provide similar services, operators $\&$ agents and finally the clients. Meanwhile, in the field of marketing, the obligations of tourism operators are referred to the services being offered by various categories of suppliers (Ganesan et al., 2009). In this regard, the title of tourism operator has good contribution. SCM in the field of tourism covers various fields like hotel industry, transport industry, restaurant and other entertainment activities (Evans, 2015). in this regard, an integrated system is very much necessary specifically from the context of SCM in the field of tourism (Song, 2012). In the field of the hotel industry, the idea of the supplier, how to conduct the communication with them, management of stock in the inventory of the business, and finally the delivery time are required to fulfil the customers' needs. In the field of tourism, the concept of a supply chain's performance is measured through operational and financial outcomes. For instance, some significant approaches like lowering the lead time, keeping the exact quantities for the order and finally management of communication with the key suppliers (Rasool et al., 2016; Yu-Chi \& Lin, 2018).

Supply chain management in the tourism industry has also considered factors like market share, cost, along with some non-financial measures (Allayannis et al., 2001). However, the concept of customer satisfaction, significant efficiency in the internal processing system, along with the level of innovation are among the main contributors to the integration of supply chain and tourism. Meanwhile, the key parties involved in the supply chain can also be examined through their participations. Various reasons have been examined for the tourism chain based on the companies, the attraction of location along with other facilities provided by the government (Tarí et al., 2010; Ţigu \& Călăreţu, 2013; Erdogan, 2016; Mayan \& Nor, 2017). In addition, it is also observed when studying the tourism supply chain, the elements like strategies, concepts, channels of distribution, along with competitive advantage, association in the marketplace (Kotler \& Gertner, 2002). Besides, the factors like performance measurement through the satisfaction of tourists, financial performance, operational performance, and finally the sustainable development in the field of tourism are some indicators being observed in the literature (Choi \& Turk, 2011; Haber \& Reichel, 2005; Inoue \& Lee, 2011).

However, the participants in the form of operators in the supply chain of tourism are also working for the improved business performance and more share in the marketplace. These participants are also working for a competitive advantage in the field of tourism while attracting more tourists to their regions of interest (Chen \& Paulraj, 2004). In this regard, the selection process of the contractor process is very complex which necessitates a significant commitment of potential partners (McKercher, 2003). Such integration can result in more output of the revenue for the government and private sector, along with customer satisfaction.

\section{Variables and Methods}

The focus of the present study is to study the integration between the supply chain management (SCM) and tourism industry in the region of Indonesia. To explore this association, SCM is considered as the main explanatory variable of the study. To measure the SCM, various items belong to supply chain have been added in the survey questionnaire, under the definition of Strategic Supplier Partnership, Information Sharing, Information Quality and finally, Supplier Performance are added in the model. For each of the stated factors, at least four dimensions have been added in the questionnaire. Overall 16 items have been finalized for SCM. For the tourism industry, four items under the title of THI1 to THI4 have been added in the questionnaire. To study the dimensions of various respondents, demographic factors under the title of age, gender and qualification are under consideration. After the finalization of the questionnaire, it is presented to the various respondents linked to the tourism industry in the form hotel sector working in different parts of Indonesia. A sample of 272 respondents have been 
accepted for the further demographic and regression analysis of the study. For the demographic analysis, frequency tables along with pie-charts have been presented in the section of analysis and discussion. For the empirical facts, four regression models have been tested while taking each proxy of tourism THI1-THI4 as a major dependent variable of the study. The empirical findings are generated and presented through their coefficients, robust standard error and explained variation for the overall significance of each model. Fig. 2 explains the model of the study, taking SCM key components, and tourism hotel industry THI1-THI4.

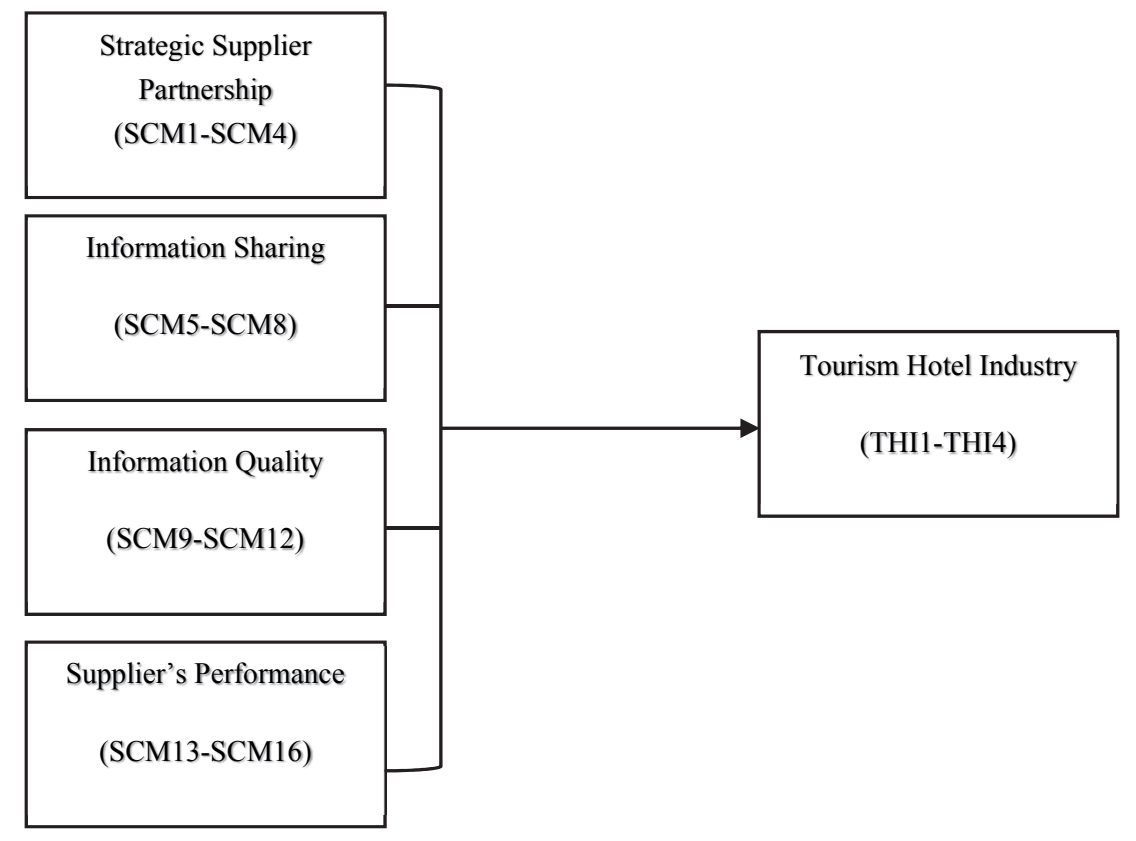

Fig. 2. Model of the Study

Source: Author's observations based on past literature

\section{Results and Discussions}

Fig. 3 indicates the output for the demographic characteristics of the respondents.

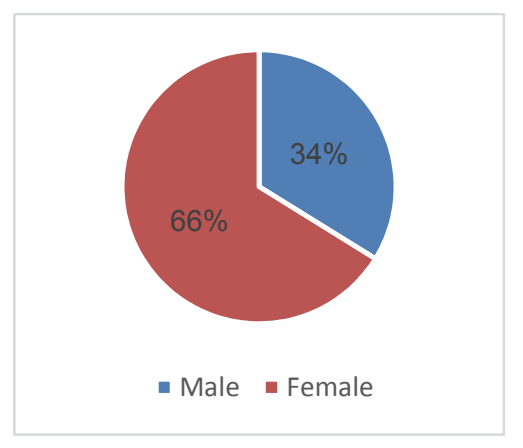

Gender

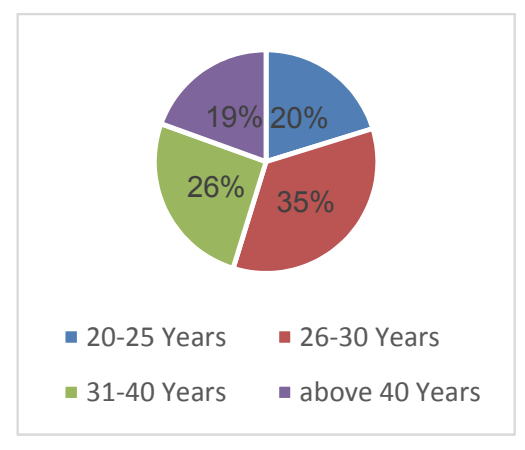

Age

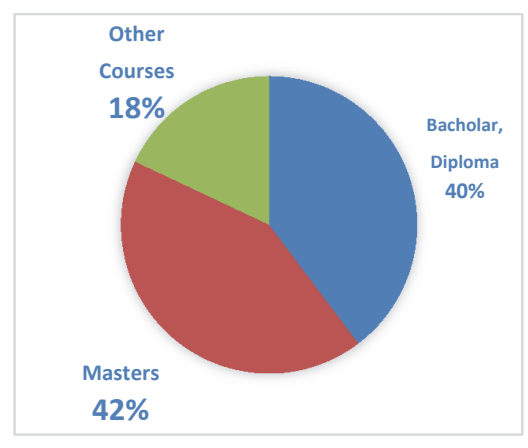

Educational background

Fig. 3. Personal characteristics of the respondents

A total sample of 272 respondents has been finalized from those industries which are dealing with the tourism industry supply of related products. Out of a total sample of 272, 180 which are presenting 66.2 percent sample are males, while 92 are female, covering a sample of 33.8 percent. In terms of age ranges, 55 belongs to the age category of 20-25 years, 94 belongs to 26-30 years, 70 belongs to 31-40 years and finally, 53 respondents have the age category of 40 plus. These ranges covering the sample portion of 20.2 percent, 34.6 percent, 25.7 percent and finally 19.5 percent, respectively. In terms of 
qualification, out of a total sample of 272 respondents, 108 have completed their bachelor, diploma covering a sample size of 39.7 percent. For the master's degree holders, 115 respondents with the portion of 42.3 percent. Meanwhile, for those having some other courses or degrees are 49 with the percentile of 18 in the overall sample of the study. Fig. 3 shows personal characteristics of the participants. Table 1 indicates the overall trends in the data set through total observation of each variable, mean score, the standard deviation in the mean, along with minimum and maximum ranges of the study. To measure the factor of supply chain management, sixteen dimensions from SCM1 to SCM16 have been added which are extracted from existing literature. For the Tourism industry, 4 items under the title of tourism products \& industry or THI1 to THI4 have been added. The mean score for the SCM1 is 3.85 explains an average trend near to $4^{\text {th }}$ point on the liker scale. For SCM2, the average value is 4.051 with the standard deviation of .986 with the range of 1 to 5 on Likert scale. The mean score for SCM8 indicates that on average, respondents did not agree with the supply chain practices conducted by the company. For the rest of the indicators under the descriptive findings indicate above the neutral point with the mean score of above 3 on the Likert scale. The maximum average score belongs to SCM2 while minimum score belongs to SCM8. For THI, all items are indicating above 3.50 but below 4 mean scores.

\section{Table 1}

Descriptive Findings

\begin{tabular}{|c|c|c|c|c|c|}
\hline Variable & Obs & Mean & Std.Dev. & Min & Max \\
\hline SCM1 & 272 & 3.853 & 1.104 & 1 & 5 \\
\hline SCM2 & 272 & 4.051 & .986 & 1 & 5 \\
\hline SCM3 & 272 & 2.346 & 1.595 & 1 & 5 \\
\hline SCM4 & 272 & 3.901 & 1.091 & 1 & 5 \\
\hline SCM5 & 272 & 3.765 & 1.186 & 1 & 5 \\
\hline SCM6 & 272 & 3.827 & 1.157 & 1 & 5 \\
\hline SCM7 & 272 & 3.857 & 1.155 & 1 & 5 \\
\hline SCM8 & 272 & 2.162 & 1.484 & 1 & 5 \\
\hline SCM9 & 272 & 3.107 & 1.331 & 1 & 5 \\
\hline SCM10 & 272 & 3.287 & 1.136 & 1 & 5 \\
\hline SCM11 & 272 & 3.849 & 1.118 & 1 & 5 \\
\hline SCM12 & 272 & 3.919 & 1.107 & 1 & 5 \\
\hline SCM13 & 272 & 3.224 & 1.519 & 1 & 5 \\
\hline SCM14 & 272 & 3.893 & 1.08 & 1 & 5 \\
\hline SCM15 & 272 & 3.665 & 1.301 & 1 & 5 \\
\hline SCM16 & 272 & 3.779 & 1.167 & 1 & 5 \\
\hline THI1 & 272 & 3.875 & 1.13 & 1 & 5 \\
\hline THI2 & 272 & 3.342 & 1.514 & 1 & 5 \\
\hline THI3 & 272 & 3.511 & 1.427 & 1 & 5 \\
\hline THI4 & 272 & 3.761 & 1.18 & 1 & 5 \\
\hline
\end{tabular}

Table 2 expresses regression findings for item 1 and 2 for THI. Under the title of Model 1-THI, the effect of various items of SCM has been empirically examined and presented. For SCM1 the effect is -.133, which indicates that "Strategic supplier partnership" or SCM1 has its negative and significant impact on THI1. The value of standard deviation in the coefficient of SCM1 is -.0559, indicating a low level of error. The coefficient of SCM4 is .0928, which indicates information sharing under the title of SCM4 or "We and our suppliers exchange information that helps the establishment of business planning" are positively and significantly affecting the THI1. The value of the standard error is .0661. For SCM7, the value of the coefficient is .467 which indicates a positive and significant influence on THI1. The same positive and significant impact of .227 has been recorded through SM11. For SCM16, the effect is .149 and also explains its significant and positive influence with the value of .149 and standard error of -.0764 . The rest of the indicators have their insignificant influence on THI1 as well.

For model 2, the factor of THI2, has explained the fact that SCM1 has its significant and negative impact of -.135 on the value of THI2 for the whole sample of the study. This impact is like model 1 where strategic supplier partnership (a factor of supply chain management) which have symmetrical 
significant and negative impact on THI1. The effect of SCM3 for THI2 is also significant and negative with the coefficient of -.164 and standard error of -.0737. For SCM8 the effect of .141 with the standard error of -.0535 is found which implies that increasing value of SCM8 can put a positive influence on THI2. For model two, the significant contribution while explaining THI2, the contribution of SCM13 and SCM15 is .197 and .291 indicating their significant positive impacts. The overall value of robust R-Square is .87 percent for model 1 and for model two, this value is .91 percent implies a high level of explained variation due to all indicators of SCM1 to SCM16 for THI1 and THI2. The number of observations under model 1 and 2 are 272 indicating that all the respondents have been under consideration for empirical analysis.

Table 2

$\underline{\text { Regression Coefficients and Standard error for Model } 1 \text { and Model } 2}$

\begin{tabular}{|c|c|c|}
\hline VARIABLES & $\begin{array}{c}(1) \\
\text { Model 1-THI1 }\end{array}$ & $\begin{array}{c}\text { (2) } \\
\text { Model 2-THI2 }\end{array}$ \\
\hline scm1 & $\begin{array}{c}-0.133^{* *} \\
(0.0559)\end{array}$ & $\begin{array}{l}-0.135^{*} \\
(0.0775)\end{array}$ \\
\hline $\mathrm{scm} 2$ & $\begin{array}{c}0.0379 \\
(0.0629)\end{array}$ & $\begin{array}{c}-0.0453 \\
(0.0829)\end{array}$ \\
\hline $\mathrm{scm} 3$ & $\begin{array}{l}-0.0406 \\
(0.0503)\end{array}$ & $\begin{array}{c}-0.171 * * * \\
(0.0522)\end{array}$ \\
\hline $\mathrm{scm} 4$ & $\begin{array}{l}0.0928^{* *} \\
(0.0661)\end{array}$ & $\begin{array}{c}0.0558 \\
(0.0701)\end{array}$ \\
\hline $\mathrm{scm} 5$ & $\begin{array}{l}-0.00859 \\
(0.0666)\end{array}$ & $\begin{array}{l}-0.164 * * \\
(0.0737)\end{array}$ \\
\hline scm6 & $\begin{array}{l}-0.0894 \\
(0.0716)\end{array}$ & $\begin{array}{c}0.0290 \\
(0.0726)\end{array}$ \\
\hline $\mathrm{scm} 7$ & $\begin{array}{l}0.467 * * * \\
(0.0738)\end{array}$ & $\begin{array}{c}-0.109 \\
(0.0818)\end{array}$ \\
\hline scm8 & $\begin{array}{c}0.0301 \\
(0.0483)\end{array}$ & $\begin{array}{l}0.141^{* * *} \\
(0.0535)\end{array}$ \\
\hline scm9 & $\begin{array}{c}0.0366 \\
(0.0475)\end{array}$ & $\begin{array}{l}-0.0750 \\
(0.0701)\end{array}$ \\
\hline $\operatorname{scm} 10$ & $\begin{array}{l}-0.0423 \\
(0.0679)\end{array}$ & $\begin{array}{l}0.147^{* *} \\
(0.0716)\end{array}$ \\
\hline $\mathrm{scm} 11$ & $\begin{array}{l}0.227 * * * \\
(0.0752)\end{array}$ & $\begin{array}{l}-0.0641 \\
(0.0798)\end{array}$ \\
\hline $\mathrm{scm} 12$ & $\begin{array}{l}-0.0585 \\
(0.0730)\end{array}$ & $\begin{array}{l}0.311^{* * *} \\
(0.0866)\end{array}$ \\
\hline $\mathrm{scm} 13$ & $\begin{array}{c}0.0416 \\
(0.0514)\end{array}$ & $\begin{array}{l}0.197 * * * \\
(0.0602)\end{array}$ \\
\hline $\mathrm{scm} 14$ & $\begin{array}{l}-0.0154 \\
(0.0630)\end{array}$ & $\begin{array}{l}0.00966 \\
(0.0691)\end{array}$ \\
\hline $\operatorname{scm} 15$ & $\begin{array}{l}-0.0320 \\
(0.0621)\end{array}$ & $\begin{array}{l}0.291 * * * \\
(0.0721)\end{array}$ \\
\hline $\mathrm{scm} 16$ & $\begin{array}{c}0.149^{*} \\
(0.0764)\end{array}$ & $\begin{array}{l}-0.0444 \\
(0.0748)\end{array}$ \\
\hline Constant & $\begin{array}{l}1.337^{*} \\
(0.766)\end{array}$ & $\begin{array}{c}2.061 * * \\
(0.954)\end{array}$ \\
\hline $\begin{array}{l}\text { Observations } \\
\text { R-squared }\end{array}$ & $\begin{array}{c}272 \\
0.364\end{array}$ & $\begin{array}{c}272 \\
0.232\end{array}$ \\
\hline
\end{tabular}

Robust standard errors in parentheses ${ }^{* * *} \mathrm{p}<0.01,{ }^{* *} \mathrm{p}<0.05,{ }^{*} \mathrm{p}<0.1$

Table 3 expresses regression findings for item 3 and 4 for THI. Under the title of Model 3-THI3, the effect of various items of SCM have been empirically examined and presented. For SCM1 the effect is -.0112 indicates that "Strategic supplier partnership" or SCM1 has its negative and significant impact on THI3. The value of standard deviation in the coefficient of SCM2 is -.185, indicating a low level of error. The effect of SCM3 is also significant and -.111 explains their negative influence on THI3. The coefficient of SCM4 is -.110 indicates information sharing under the title of SCM4 or "We and our suppliers exchange information that helps the establishment of business planning" are positively but significantly affecting the THI1. The value of the standard error is .0854. For SCM7, the value of the 
coefficient is .0373 indicates a positive and significant influence on THI3. The rest of the indicators have their insignificant influence on THI1 as well.

For model 2 the factor of THI4, explained the fact that SCM1 has its significant and negative impact of -.0423 on the value of THI 4 for the whole sample of the study. This impact is like model 1 where strategic supplier partnership (a factor of supply chain management) which have symmetrical significant and negative impact on THI1, THI2, and THI3. The effect of SCM3 for THI2 is insignificant and negative with the coefficient of -.00983 and standard error of -.0478. The factors from SCM5 to SCM8 on THI4 is insignificant. For SCM9 the effect of .172 with the standard error of -.0615 is found which implies that increasing value of SCM8 can put a positive influence on THI4. For model 4, the significant contribution while explaining THI4, the contribution of SCM13 and SCM14 is .144 and .164 indicating their significant positive impact. The overall value of robust R-Square is .721 percent for model 3 and for model 4, this value is .693 percent implies a high level of explained variation due to all indicators of SCM1 to SCM16 for THI3 and THI4. The number of observations under model 3 and 4 is also the same; 272.

\section{Table 3}

Regression Coefficients and Standard error for Model 3 and Model 4

\begin{tabular}{|c|c|c|}
\hline VARIABLES & $\begin{array}{c}\text { (1) } \\
\text { Model } 3 \text { THI-3 }\end{array}$ & $\begin{array}{c}(2) \\
\text { Model } 4 \text { THI-4 }\end{array}$ \\
\hline SCM1 & $\begin{array}{c}-0.0112 * * \\
(0.0964)\end{array}$ & $\begin{array}{c}-0.0423^{*} \\
(0.0683)\end{array}$ \\
\hline SCM2 & $\begin{array}{l}-0.185^{*} \\
(0.103)\end{array}$ & $\begin{array}{l}-0.0535 \\
(0.0737)\end{array}$ \\
\hline SCM3 & $\begin{array}{l}-0.111^{*} \\
(0.0632)\end{array}$ & $\begin{array}{l}-0.00983 \\
(0.0478)\end{array}$ \\
\hline SCM4 & $\begin{array}{c}-0.110 \\
(0.0854)\end{array}$ & $\begin{array}{c}-0.104 \\
(0.0681)\end{array}$ \\
\hline SCM5 & $\begin{array}{l}-0.0639 \\
(0.0791)\end{array}$ & $\begin{array}{c}0.0515 \\
(0.0657)\end{array}$ \\
\hline SCM6 & $\begin{array}{c}0.0710 \\
(0.0955)\end{array}$ & $\begin{array}{l}-0.0239 \\
(0.0689)\end{array}$ \\
\hline SCM7 & $\begin{array}{l}0.0373^{*} \\
(0.0837)\end{array}$ & $\begin{array}{c}0.0252 \\
(0.0605)\end{array}$ \\
\hline SCM8 & $\begin{array}{l}0.153^{* *} \\
(0.0665)\end{array}$ & $\begin{array}{l}-0.0624 \\
(0.0545)\end{array}$ \\
\hline SCM9 & $\begin{array}{l}-0.0992 \\
(0.0720)\end{array}$ & $\begin{array}{l}0.172 * * * \\
(0.0615)\end{array}$ \\
\hline SCM10 & $\begin{array}{c}-0.137 \\
(0.0841)\end{array}$ & $\begin{array}{l}0.00180 \\
(0.0593)\end{array}$ \\
\hline SCM11 & $\begin{array}{c}0.0348 \\
(0.0884)\end{array}$ & $\begin{array}{l}-0.0635 \\
(0.0652)\end{array}$ \\
\hline SCM12 & $\begin{array}{c}0.0706 \\
(0.0970)\end{array}$ & $\begin{array}{c}0.127^{*} \\
(0.0660)\end{array}$ \\
\hline SCM13 & $\begin{array}{c}0.0998 \\
(0.0718)\end{array}$ & $\begin{array}{l}0.144^{* *} \\
(0.0558)\end{array}$ \\
\hline SCM14 & $\begin{array}{l}0.236^{* * * *} \\
(0.0874)\end{array}$ & $\begin{array}{l}0.164 * * \\
(0.0751)\end{array}$ \\
\hline SCM15 & $\begin{array}{l}-0.0191 \\
(0.0765)\end{array}$ & $\begin{array}{c}0.0657 \\
(0.0673)\end{array}$ \\
\hline SCM16 & $\begin{array}{c}0.176^{*} \\
(0.0976)\end{array}$ & $\begin{array}{l}-0.0707 \\
(0.0682)\end{array}$ \\
\hline Constant & $\begin{array}{c}3.001 * * * \\
(0.909)\end{array}$ & $\begin{array}{c}2.638^{* * *} \\
(0.794)\end{array}$ \\
\hline $\begin{array}{l}\text { Observations } \\
\text { R-squared }\end{array}$ & $\begin{array}{c}272 \\
0.721 \\
\end{array}$ & $\begin{array}{c}272 \\
0.693 \\
\end{array}$ \\
\hline
\end{tabular}




\section{Conclusion and Recommendations}

In conclusion, the topic of supply chain management and its integration with the tourism industry is a new dimension in the present literature. Although the traditional meaning of SCM is very well examined and justified in various studies from both theoretical and empirical perspective. However, the idea of SCM and its association with the tourism industry while the major focus is on the strategic supplier partnership is not very well addressed from the research context. The review of various studies has provided a significant pathway to cover this gap from the context of Indonesia, while taking those firms which are purely dealing with the tourism industry. To consider the factor of SCM, overall sixteen dimensions have been identified from the previous literature and added in the questionnaire of the study. The key focus of these items is on the strategic supplier partnership, information sharing, information quality and performance of the suppliers. For all of the items, four proxies have been added in the questionnaire. For the tourism industry, four items under the title of THI1 to THI4 have been added. To analyze the empirical association between SCM items and tourism industry, all items of THI1 have been separately regressed and presented under the title of model 1-4. Demographic analysis has been conducted for the gender, age and qualification categories for the overall sample of 272 respondents. The findings under model 1 indicates that SCM proxies under the title of SCM1, SCM7, SCM11 and SCM16 have maintained their significant influence on THI1. For the model two, the proxies under the title of SCM1, SCM5, SCM8, SCM10, SCM12, SCM13 and SCM15 have kept their significant influence on THI2. For the model three, the impact of SCM1, SCM2, SCM3, SCM7, SCM8, SCM14, and SCM16 were significantly impacting on THI3. Moreover, for the model 4, the impact of SCM1, SCM9, SCM12, SCM13, and SCM14 have explained their meaningful effect. The value of explained variations for all the models have indicated a good variation in all the proxies of the tourism industry. All these findings have indicated the fact that respondents in the field of the tourism industry were highly concerned with the SCM and related practices.

For the future studies and their implications, this study has considered various limitations which can be considered. At first, this study has considered the one industry related to the tourism which is hotels while ignoring the other firms working in the same industry. At second, the sample size is in a reasonable number but not very good for the generalizability and more application from the context of management. At third, the methodological portion is lacking the structural modelling and advanced techniques with more significant findings. In the last, this study has not focused on the cross-sectional analysis of SCM and other firms working in the tourism industry of Indonesia. While adding these limitations, the present gap of the study can be overcome in the coming time. However, from the context of implications, this study can be significant for the management of the hotel industry specifically and other key decision makers who are directly or indirectly involved in tourism. Besides, the idea of SCM is very well discussed from the context of suppliers and product delivery which can satisfy customer needs. To increase the performance of various activities under the title of SCM, there is a strong need of integration with the key suppliers. The analysis based on the respondents have indicated some of the good dimensions of SCM and their impacts on the value of the tourism industry. To increase the quality improvement of services in the hotel industry, the implementation of quality management is another topic to be covered in upcoming studies from the context of tourism and supply chain management.

\section{References}

Alford, P. (2005). A framework for mapping and evaluating business process costs in the tourism industry supply chain. Information and Communication Technologies in Tourism 2005, 125-136.

Allayannis, G., Ihrig, J., \& Weston, J. P. (2001). Exchange-rate hedging: Financial versus operational strategies. American Economic Review, 91(2), 391-395.

Ashworth, G., \& Voogd, H. (1994). Marketing of tourism places: What are we doing? Journal of International Consumer Marketing, 6(3-4), 5-19.

Briandana, R., Doktoralina, C. M., \& Sukmajati, D. (2018). Promotion analysis of marine tourism in Indonesia: A case study. European Research Studies Journal, 21(2), 602-613. 
Buhalis, D., \& Law, R. (2008). Progress in information technology and tourism management: 20 years on and 10 years after the Internet-The state of eTourism research. Tourism Management, 29(4), 609-623.

Chen, I. J., \& Paulraj, A. (2004). Towards a theory of supply chain management: the constructs and measurements. Journal of Operations Management, 22(2), 119-150.

Choi, H. C., \& Turk, E. S. (2011). Sustainability indicators for managing community tourism. In Quality-of-life Community Indicators for Parks, Recreation and Tourism Management (pp. 115-140). Springer, Dordrecht.

Eraqi, M. I. (2006). Tourism services quality (TourServQual) in Egypt: The viewpoints of external and internal customers. Benchmarking: An International Journal, 13(4), 469-492.

Erdogan, A. I. (2016). Investigating the Demand of Small Hotel and Restaurant Businesses for Bank Financing: The Case of Turkey. Journal of Empirical Studies, 3(1), 1-6.

Evans, N. (2015). Strategic management for tourism, hospitality and events. Routledge.

Ganesan, S., George, M., Jap, S., Palmatier, R. W., \& Weitz, B. (2009). Supply chain management and retailer performance: emerging trends, issues, and implications for research and practice. Journal of Retailing, 85(1), 84-94.

García-Rosell, J.-C., Haanpää, M., Kylänen, M., \& Markuksela, V. (2007). From firms to extended markets: A cultural approach to tourism product development. Turizam: međunarodni znanstvenostručni časopis, 55(4), 445-459.

Haber, S., \& Reichel, A. (2005). Identifying performance measures of small ventures - the case of the tourism industry. Journal of Small Business Management, 43(3), 257-286.

Hussien, F. M., \& Jones, E. (2016). The requirements of disabled customers: a study of British customers in Egyptian hotels. Journal of Tourism Management Research, 3(2), 56-73.

Inoue, Y., \& Lee, S. (2011). Effects of different dimensions of corporate social responsibility on corporate financial performance in tourism-related industries. Tourism Management, 32(4), 790-804.

Khan, R. E. A., \& Rasheed, M. K. (2016). Political economy of tourism in Pakistan: The role of terrorism and infrastructure development. Asian Development Policy Review, 4(2), 42-50.

Kotler, P., \& Gertner, D. (2002). Country as brand, product, and beyond: A place marketing and brand management perspective. Journal of Brand Management, 9(4), 249-261.

Mayan, S. N. A., \& Nor, R. M. (2017). Prospects and Challenges of Ecotourism Sector and Poverty Eradication in Sabah: The Case of Orangutans and Mabul Island. Global Journal of Social Sciences Studies, 3(1), 1-12.

McKercher, B. (2003). Sustainable tourism development-guiding principles for planning and management. Paper presented at the National seminar on sustainable tourism development, Bishkek, Kyrgystan.

Muhcină, S., \& Popovici, V. (2008). Ethics in marketing communication. Management \& Marketing, 3(2), 67-77.

Okon, E. O. (2014). Inbound Tourism and Social Factors in Nigeria: Evidence from an Ardl-Ecm Model. Asian Journal of Economics and Empirical Research, 1(2), 40-47.

Rasool, Y., Iftikhar, B., Nazir, M. N., \& Kamran, H. W. (2016). Supply chain evolution and green supply chain perspective. International Journal of Economics, Commerce and Management, 4(10), 716-724.

Sigala, M. (2008). A supply chain management approach for investigating the role of tour operators on sustainable tourism: the case of TUI. Journal of Cleaner Production, 16(15), 1589-1599.

Song, H. (2012). Tourism supply chain management. Routledge.

Szpilko, D. (2017). Tourism supply chain-overview of selected literature. Procedia Engineering, 182, 687-693.

Taqi, M., Ajmal, M \& Ansari, M.S (2018). Financial efficiency of India tourism development corporation (ITDC) limited: An empirical study. Journal of Tourism Management Research, 5(1), 14-22.

Tarí, J. J., Claver-Cortés, E., Pereira-Moliner, J., \& Molina-Azorín, J. F. (2010). Levels of quality and environmental management in the hotel industry: Their joint influence on firm performance. International Journal of Hospitality Management, 29(3), 500-510. 
Ţigu, G., \& Călăreţu, B. (2013). Supply chain management performance in tourism. Continental hotels chain case. Amfiteatru Economic Journal, 15(33), 103-115.

Yu-Chi, S. (2018). Revisiting the tourism-led growth hypothesis in a dual model using Mwald Granger causality analysis. Asian Economic and Financial Review, 8(8), 1102-1110.

Yu-Chi, S., \& Lin, H. P. (2018). Causality relationship between tourism, Foreign direct investment and economic growth in Taiwan. Asian Journal of Economic Modelling, 6(3), 287-293.

Zhang, H. Q., Chong, K., \& Ap, J. (1999). An analysis of tourism policy development in modern China. Tourism Management, 20(4), 471-485.

Zhang, J., Inbakaran, R. J., \& Jackson, M. S. (2006). Understanding community attitudes towards tourism and host - Guest interaction in the urban-rural border region. Tourism Geographies, 8(2), 182204.

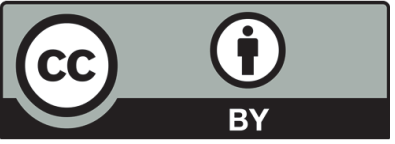

(C) 2019 by the authors; licensee Growing Science, Canada. This is an open access article distributed under the terms and conditions of the Creative Commons Attribution (CC-BY) license (http://creativecommons.org/licenses/by/4.0/). 